\title{
IBRN Initiative \\ on Interactions of Monetary and Prudential Policies
}

\author{
Konstantin Styrin, Bank of Russia \\ styrinka@cbr.ru \\ Yulia Ushakova, Bank of Russia \\ ushakovayuv@mail.cbr.ru
}

This paper surveys a recent IBRN initiative that studied the interactions of monetary and macroprudential policies. The general research questions is: To what extent does macroprudential policy reshape the transmission of monetary policy? The concrete context differs across studies. There are three main findings. First, domestic prudential policy in recipient economies can partially offset inward transmission from systemic economies to domestic lending, with the size of the effect being heterogeneous across banks in source countries. Second, the stance of prudential policy in the source economy also matters and can affect the intensity of outward monetary transmission. Finally, there is much heterogeneity in the strength of effect across different prudential instruments.

Keywords: monetary policy, prudential policy, policy interaction, cross-border policy spillovers, bank lending

JEL Codes: G21, G28, E52, E58
Citation: Styrin, K. and Ushakova, Y. (2020). IBRN Initiative on Interactions of Monetary and Prudential Policies. Russian Journal of Money and Finance, 79(3), pp. 58-74.

doi: $10.31477 /$ rjmf.202003.58

The International Banking Research Network (IBRN) is a recurring collaboration of central banks around the globe that aims to investigate important policy-related research questions using the confidential granular data available to national research teams and applying a similar methodology. This approach allows the running of a meta-analysis and thus the obtaining of a 'big picture' of comparable empirical findings across different countries. At the time of writing, there are 28 members of the IBRN, including the central banks of advanced economies and emerging market economies and two supranational bodies, the International Monetary Fund (IMF) and the Bank for International Settlements (BIS). The Bank of Russia has participated in IBRN initiatives since 2016.

One of the two most recent IBRN research initiatives studied the interaction between monetary and macroprudential policies. The topic is related to several 
pieces of existing literature. First, as argued, for instance, in Repullo and Suarez (2013), the credit, or financial cycle, on the one hand, and the business cycle, on the other hand, are not necessarily synchronised, and this implies that monetary policy alone cannot serve as the means to smooth both cycles. This gives rise to a role for macroprudential policy in softening the financial cycle and, thus, promoting financial stability, while leaving responsibility for price and output stability to monetary policy. There has been, however, some skepticism with regard to the efficacy of macroprudential policy tools, such as countercyclical capital buffers (CCyB), loan-to-value (LTV) and debt-to-income (DTI) caps, etc., and this has persisted because many such tools were previously untested. Furthermore, the simultaneous implementation of several policies makes it difficult to isolate the effect of any individual one. Finally, given that macroprudential policies are applied in response to developments in the financial sector, the identification of their causal effect on credit growth, risk-taking, and so on by isolating the exogenous components of the policy remains a serious challenge. A consensus on the potency of macroprudential policies to curb the financial cycle and the unwanted accumulation of disbalances in the financial system it causes is yet to be reached. For example, Blanchard (2017) views prudential capital controls as a natural tool for emerging market economies to insulate themselves from external shocks whereas Rajan (2015) argues that their potency is elusive. Empirical evidence is inconclusive: some studies document statistically and economically significant effects, while others find the opposite. Such a situation forces many to view monetary policy as a better tool for ensuring financial and macroeconomic stability, as summarised in the famous statement, from then-Federal Reserve Governor Jeremy Stein, that monetary policy is preferred since 'it gets in all of the cracks' (Stein, 2013).

The second set of literature that inspired this IBRN initiative is that on international monetary transmission and the Global Financial Cycle. It is well documented that monetary loosening in central economies such as the US and the euro area leads to a softening of financial conditions in peripheral economies, including emerging markets, and that this occurs in economies with both fixed and flexible exchange rate regimes. Bruno and Shin (2015) find that monetary easing in the US triggers massive capital outflows from the centre to the periphery, accompanied by growth in the leverage of global banks. Passari and Rey (2015) document a great degree of co-movement in cross-border capital flows, asset prices, and leverage across countries. Miranda-Agrippino and Rey (2020) show that asset prices across the world contain a common component that explains a substantial (up to 20\%) fraction of their variation, which they label the Global Financial Cycle. Rey (2015) reports evidence that floating exchange rates do not warrant monetary policy autonomy and concludes that the Mandellian Trilemma of economic policy in an open economy has turned into a dilemma: monetary policy autonomy can be restored only if capital controls or other macroprudential policies are in place. 
As with other IBRN initiatives, this one focusses on the determinant of cross-border bank credit flows, either in the form of arm's length or of intragroup lending. This type of flow accounts for about $50 \%$ of all crossborder capital movements. The general research questions is: To what extent does macroprudential policy reshape the transmission of monetary policy? The concrete context differs across studies.

Implementation details differ across country studies. This is explained by the fact that in some countries, such as Mexico or Russia, the banking sector is oriented to serving mainly domestic customers, with no substantial footprint overseas. Other countries, such as the US or the UK, on the contrary, are home to global banks with widespread networks of branches and subsidiaries all over the world. A generic exercise can be represented by the following specification

$$
Y=\beta_{0}+\beta_{1} M+\beta_{2} P+\beta_{3} M \times P+\beta_{4} X+u,
$$

where $Y$ is the dependent variable of interest, which could be domestic or cross-border lending or lending by foreign affiliates of home banks; $M$ is some measure of a change in monetary policy stance, at home or abroad; $P$ is a proxy for the stance of prudential policy, at home or abroad; $X$ is the vector of controls, either at the bank level (liquidity ratio, log of real assets, capital ratio, core funding ratio) or at the economy level (real GDP, VIX), depending on the specific application; and $u$ is regression error that absorbs all other determinants of $Y$. The time path of ruble-denominated and foreign-currency denominated credit growth for 22 internationally active Russian banks is shown in Figures 1 and 2, respectively.

All studies but two employ confidential bank-level data that are obtained from quarterly or monthly supervisory reports that banks submit to the central bank, and this is a signature feature of this and all other IBRN initiatives. The observations are, thus, at the bank-time level, and specification (1) is a fixed effects panel regression.

Roughly, all country studies can be split into two groups, one from an inward perspective and the other from an outward perspective. A typical inward-perspective study looks at the inward transmission of monetary policy from systemic economies, such as the US, the euro area or the UK, and the effect of domestic prudential policy on this transmission. The dependent variable $Y$ in this case is some proxy for the domestic credit cycle, for example, overall credit growth or credit growth in a specific sector, e.g., mortgage lending or consumer credit. The monetary policy variable $M$ characterises the change in the stance of monetary policy in systemic economies. One possible choice of $M$ is the quarterly change in the so-called shadow policy rate (Krippner, 2015; $\mathrm{Wu}$ and Xia, 2016). The shadow rate coincides with the policy rate, which is the federal funds rate for the US outside the time period when the zero-lower 
Figure 1. Ruble-denominated credit growth for 22 internationally active Russian banks, \%

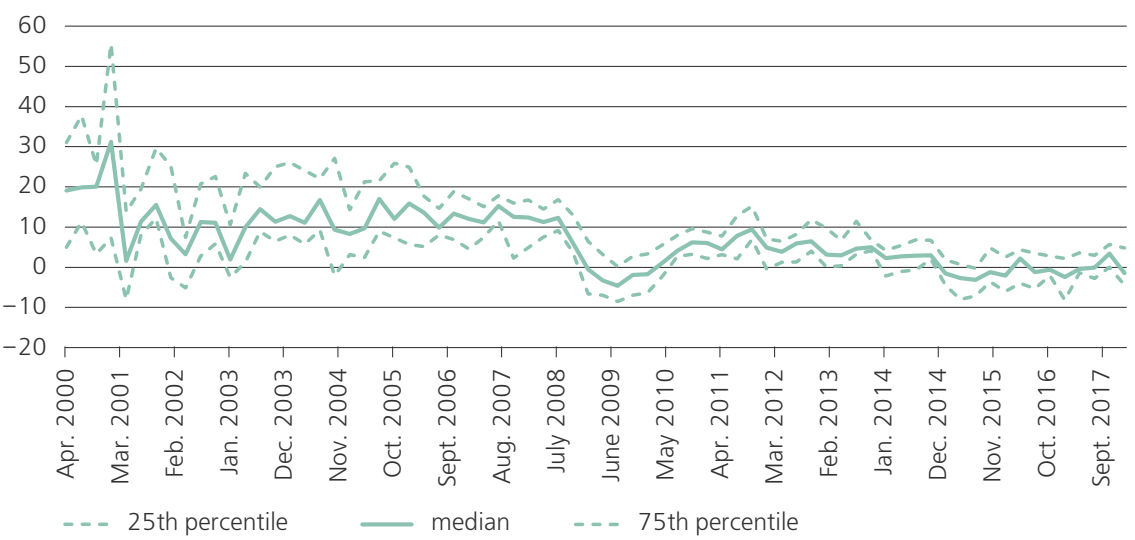

Source: Bank of Russia, authors' calculations

Figure 2. Foreign-currency-denominated credit growth for 22 internationally active Russian banks, \%

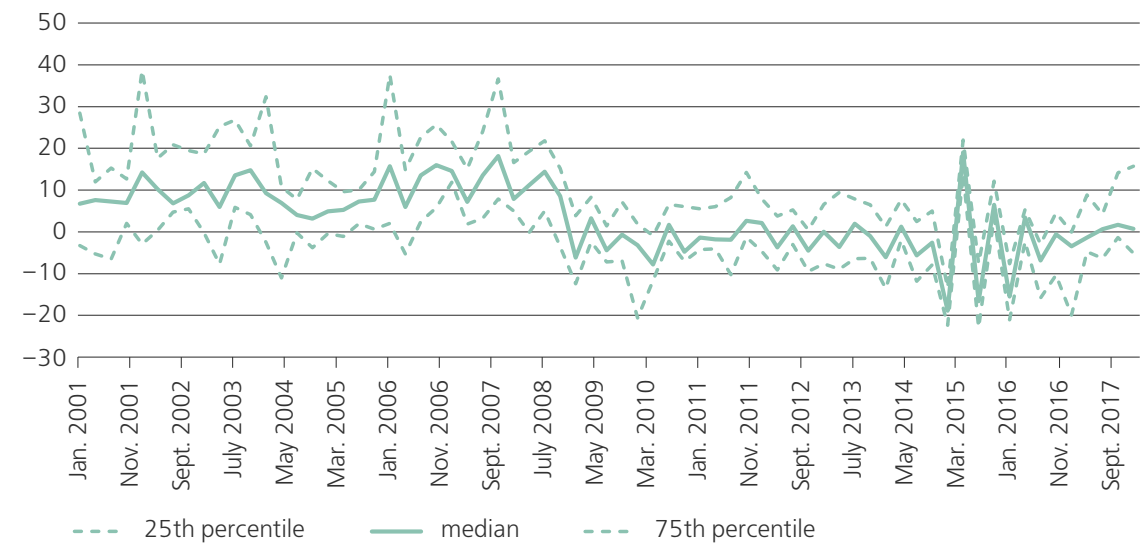

Source: Bank of Russia, authors' calculations

Figure 3. US shadow policy rate, $\%$

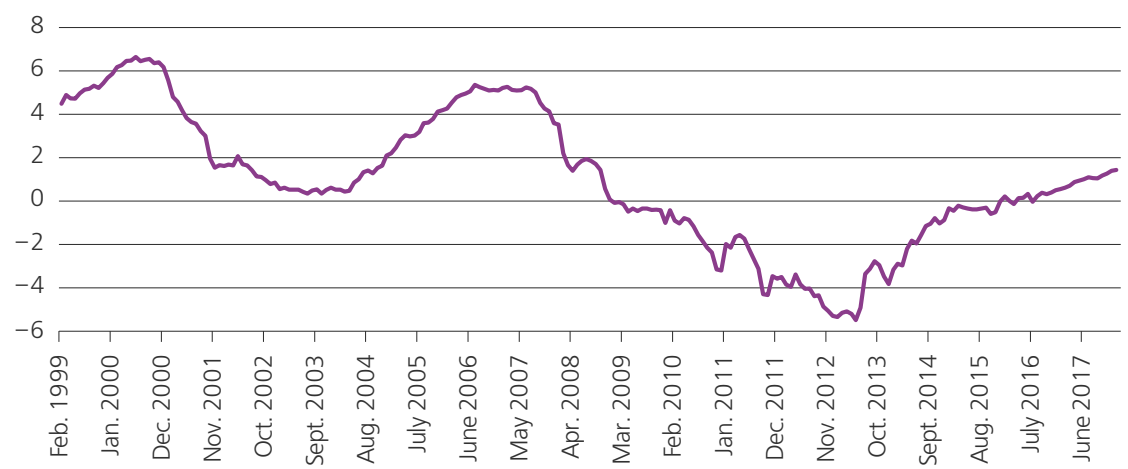

Source: Krippner (2015) 
bound (ZLB) was binding, that is, when the policy rate was close to zero (at $0.25 \%$ to be precise). Within the ZLB period, the policy rate as an indicator of monetary policy stance is likely to be uninformative. The Federal Reserve experimented with unconventional monetary policy tools during that time, such as Quantitative Easing (QE - purchases of long-term government securities on a large scale) and Forward Guidance (communicating the conditional path of the future policy rate to market participants), and it is conceivable that the contemporaneous stance of monetary policy was characterised by the negative values of the effective policy rate. Krippner (2015) and Wu and Xia (2016) derive such effective policy rate from the term structure of interest rates using a theoretical affine model of term structure in the spirit of Piazzesi (2010) and Hamilton and $\mathrm{Wu}$ (2012). The general idea is the following. By the expectation hypothesis, long-term bond yields are equal to the expected path of the shortterm rate over a horizon equal to the term to maturity for these bonds, which is postulated to be a linear function of two (as in Krippner, 2015) or three (as in Wu and Xia, 2016) latent factors. One can back out these latent factors from those parts of the yield curve that are not on the ZLB, that is, excluding bonds of short maturities. The effective short-term policy rate is then obtained as the fitted values of the postulated relationship between the short-term rate and the latent factors, where the parameters of the relationship and the latent factors themselves are estimated based on the longer-maturity part of the yield curve. The US shadow policy rate estimated in Krippner (2015) is shown in Figure 3.

An alternative choice for $M$ could be some proxy for what is called a structural monetary policy shock. A change in the effective policy rate represents a reaction from the central bank to developments in the economy. Bank credit, in turn, is likely to respond to the same developments. For example, if consumers are in the mood to spend, this will push demand for consumer credit, on the one hand, and create unwanted inflation pressures by shifting aggregate demand outwards, on the other hand. A central bank whose mandate obliges it to maintain price stability will raise the policy rate in an attempt to cool down aggregate demand and, thus, avoid higher inflation in the future. Observing a positive correlation between the contemporaneous policy rate and credit growth, a researcher might mistakenly conclude that monetary tightening has a positive causal effect on credit growth. A conventional approach that allows the avoidance of such a false conclusion is to isolate the exogenous component in the change of a monetary policy instrument. This exogenous component is unrelated to what is occurring in the economy and, therefore, can be viewed as a purely random disturbance. The identification of a structural monetary policy shock can be done within a Structural Vector Autoregression (SVAR) framework with external instruments, following Mertens and Ravn (2013) and Stock and Watson (2018). The role of external instruments is played by so-called 'monetary surprises', which are changes in the price of interest rate derivatives over a narrow 30 -minute window centred on a monetary 
policy announcement. For the US, these interest rate derivatives are federal funds rate futures contracts with different maturities (Gürkaynak et al., 2005), for the UK and the euro area these are overnight indexed swap (OIS) contracts. The idea behind this approach to the identification of structural shocks, which is often referred as high-frequency identification (HFI), is the following. Suppose that a VAR contains a sufficient number of variables so that the space of VAR innovations spans the space of structural shocks. By construction, a monetary surprise is the reaction of the financial market to news brought by a monetary policy announcement. The identifying assumption is that during the 30 -minute window there were no events other than the announcement, and, therefore, the observed change in the market price of a contract is driven completely by the news contained in the announcement. In principle, a monetary surprise itself can be used as a proxy for a monetary policy shock. One can argue, though, that this monetary surprise is likely to have a noise component, given that financial market participants may overreact or underreact to news, which is conceivable. A more rigorous approach to the identification would be to construct an OLS projection of the monetary surprise series on the space of VAR innovations. Since, by construction, the monetary surprise is uncorrelated with structural shocks other than the monetary shock, such a projection will deliver the monetary policy shock, up to a multiplicative constant. Gertler and Karadi (2015) implement this identification strategy. Their baseline VAR for the US contains four variables: industrial production, inflation, the yield on one-year government securities, and the excess bond premium, which is the credit spread for corporate bonds with the probability of default subtracted (Gilchrist and Zakrajšek, 2012). The time path of monetary surprises derived from current-month US federal funds futures (MP1) and identified US monetary policy shocks is shown in Figures 4 and 5, respectively.

Another key explanatory variable in regression (1) is $P$, the proxy for the stance of prudential policy. Compared with monetary policy, prudential policy is much more difficult to quantify. The main reason is that different types of prudential policy have their own measurement units, and it is not straightforward how exactly to aggregate them to get a meaningful single measure of prudential policy stance. For example, it is not obvious which of two prudential policy interventions, an increase in the risk weight for unsecured consumer loans by 20 percentage points (p.p.) or an increase in the reserve requirements for foreigncurrency deposits by 3 p.p., is associated with more tightening. A simple approach to the quantification of prudential policy changes is offered in Cerutti et al. (2017). This paper considers a quarterly panel of 64 countries covering the period from 2000 to 2017 and splits all prudential policies into five classes: capital buffers, interbank exposure limits, concentration limits, loan-to-value (LTV) limits, and reserve requirements. Each individual prudential policy intervention in each quarterly time period is assigned a value of 1 if it was a tightening, -1 if it was an 
Figure 4. US monetary surprises, \%

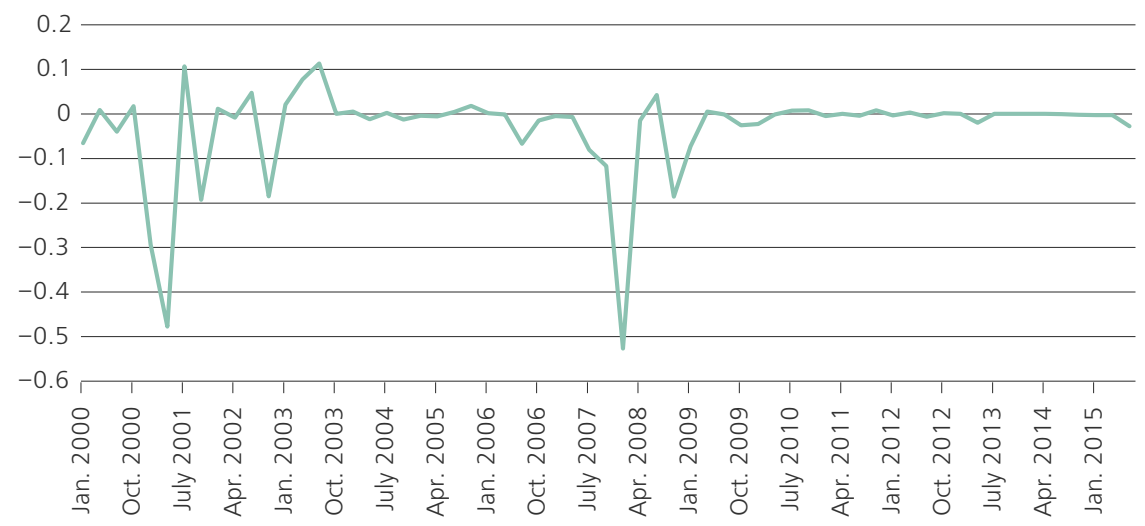

Source: IBRN

Figure 5. US monetary policy shocks identified and estimated using SVAR, $\%$

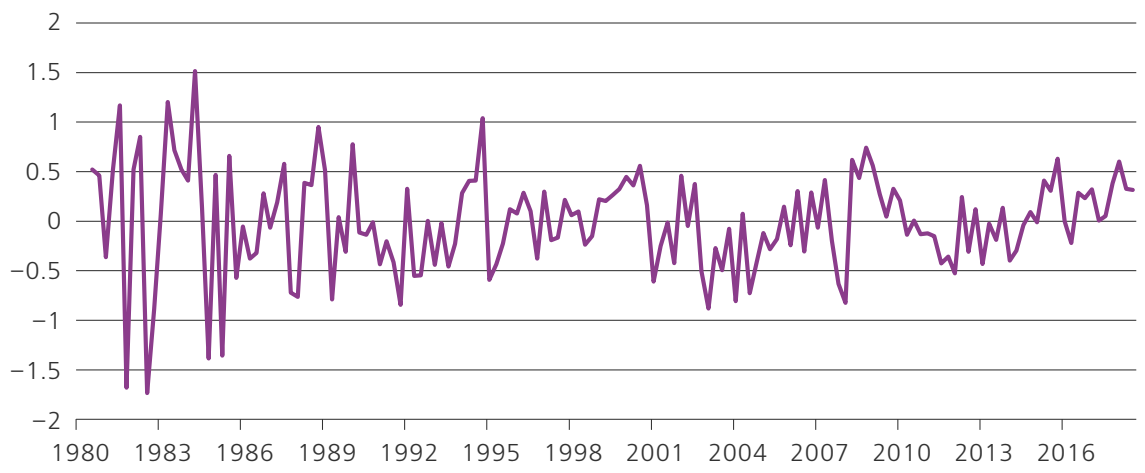

Source: IBRN

Figure 6. Aggregate prudential policy stance in Russia

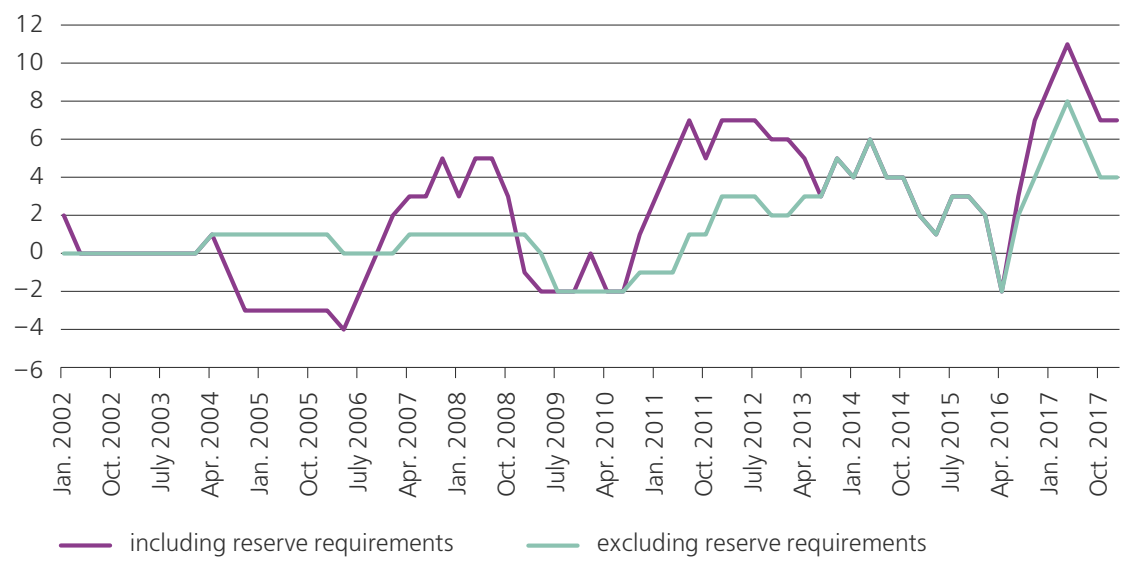

Source: Cerutti et al. (2017), authors' calculations 
easing, and 0 if there was no change. For example, on 1 April 2011, the central bank raised the reserve requirement ratio on credit institutions' liabilities to non-resident banks in all currencies from $4.5 \%$ to $5.5 \%$, the ratio on individual deposits in all currencies from $3.5 \%$ to $4 \%$, and the ratio on credit institutions' other deposits in all currencies from $3.5 \%$ to $4 \%$. This prudential action was coded as +1 . Afterwards, all individual prudential policy interventions quantified in this specific way are summed up to yield an aggregate measure for the overall stance of prudential policy. The time path of aggregate prudential policy stance in Russia is shown in Figure 6.

The term $\beta_{1} M$ in equation (1) is the distributed lag of a monetary policy shock in a systemic economy, i.e. a more precise notation would be $\beta_{1,0} M_{t}+\beta_{1,1} M_{t-1}$ $+\beta_{1,2} M_{t-2}+\beta_{1,3} M_{t-3}$. The sum of coefficients $\beta_{1,0}+\beta_{1,1}+\beta_{1,2}+\beta_{1,3}$ is the four-quarter cumulative effect of foreign monetary policy shock on domestic credit growth under the assumption that prudential policy is missing. The prudential policy stance enters the right-hand side of equation (1) as its fourth lag, i.e. $\beta_{2} P_{t-4}$. This is done in order to avoid a potential endogeneity problem since, contemporaneously, prudential policy is likely to respond to credit growth that is viewed by regulators as excessive. The regressor of interest is the interaction of the distributed lag of foreign monetary policy with the fourth lag of domestic prudential policy, i.e. $\beta_{3} M \times P$, or, more precisely, $\beta_{3,0} M_{t} \times P_{t-4}+\beta_{3,1} M_{t-1} \times P_{t-4}+\beta_{3,2} M_{t-2} \times P_{t-4}+\beta_{3,3} M_{t-3} \times P_{t-4}$. If foreign monetary policy spills over across borders, then one should expect $\beta_{1,0}+\beta_{1,1}+\beta_{1,2}+\beta_{1,3}$ to be negative: a loosening of monetary policy, say, in the US will produce capital outflows from the US and other centre economies to the periphery, and this will soften financial conditions in the recipient countries and stimulate credit growth. Similarly, if the domestic prudential policy stance has an insulating effect by alleviating the strength of international monetary transmission, then one should expect $\beta_{3,0}+\beta_{3,1}+\beta_{3,2}+\beta_{3,3}$ to be positive: a tighter prudential policy stance on the eve of monetary loosening abroad would dampen its effect on domestic credit growth.

Specification (1) assumes that all banks are equally affected by foreign monetary policy and domestic prudential policy. This is not necessarily the case, though. For example, different banks may rely on foreign funding to different degrees. It follows then that the lending of a bank with a higher fraction of foreign funding will be more sensitive to foreign monetary policy. The reason is that, due to various financial and information frictions, a bank cannot immediately reshuffle the composition of its funding mix. Similarly, the lending of a bank with a higher fraction of foreign funding will be more responsive to a domestic prudential policy intervention that explicitly targets cross-border funding, such as reserve requirements for foreign-currency deposits or interbank loans. In order to account for heterogeneous effects of policies on bank lending, specification (1) is augmented with so-called 'channel' or 'exposure' variables. One such 'channel' 
variable could be the fraction of foreign funding in liabilities. Another example is the fraction of consumer credit in assets, which is relevant for the analysis of the consequences of changing risk weights in the capital ratio for this particular asset type. The liquid asset ratio is also a potential 'channel' variable: the lending of a bank with greater liquidity buffers will be less sensitive to monetary policy tightening (Kashyap and Stein, 2000). Figures 7 and 8 show the time path of crossborder funding ratio and liquid asset ratio, respectively, for 22 internationally active Russian banks.

Figure 7. Cross-border funding ratio of 22 internationally active Russian banks, \%

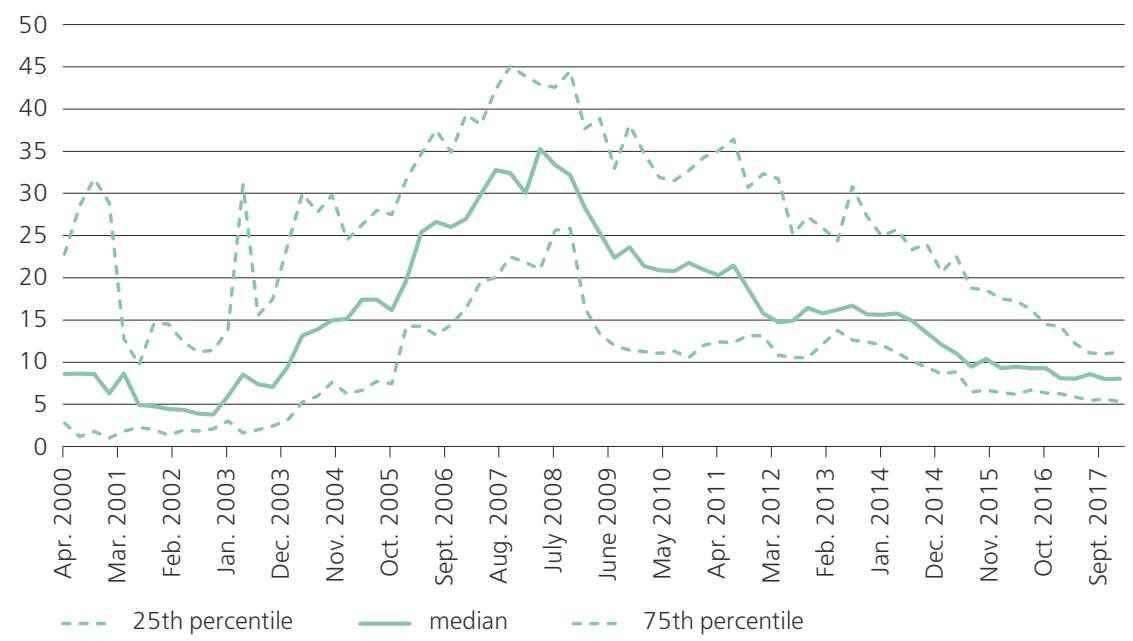

Source: Bank of Russia, authors' calculations

Figure 8. Liquid asset ratio, \%

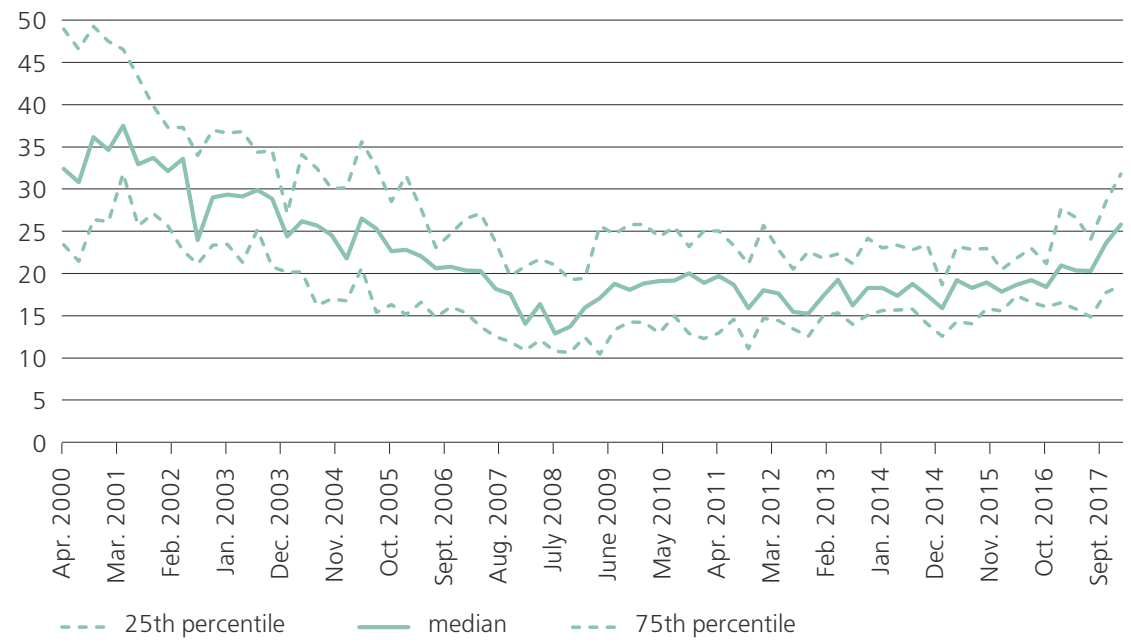

Source: Bank of Russia, authors' calculations 
The modified specification would include double and triple interactions of the respective channel variable with both policies:

$$
Y=\gamma_{0}+\gamma_{1} M \times C+\gamma_{2} P \times C+\gamma_{3} M \times P \times C+\gamma_{4} X+v,
$$

where $C$ enters the right-hand side of (2) as the fourth lag, i.e. as $C_{t-4}$. The hypothesis of interest is whether a tighter domestic prudential policy stance helps insulate bank lending from unwanted international monetary policy spillovers. Technically, it involves testing the null $\gamma_{3,0}+\gamma_{3,1}+\gamma_{3,2}+\gamma_{3,3}=0$.

Turning now to the outward perspective, which is relevant for systemic economies, such as the US, the UK, and the euro area, one can still run the analyses using specifications (1) and (2), except that $Y$ is now the cross-border lending of a home bank or the domestic lending of its foreign affiliates, $M$ is likely to be monetary policy at home, and $P$ the stance of prudential policy at home or in the destination country.

I now turn to an overview of individual studies implemented by country teams.

The study by Niepmann et al. (forthcoming) investigates the effect of stress tests in the US after 2012 on cross-border lending by the US banks to emerging markets. A stress test is an exercise that allows the evaluating of the resilience of the banking sector as a whole as well as of individual institutions to adverse shocks. Using supervisory models, the Federal Reserve projects the profitability of each bank's assets under three scenarios - baseline, adverse, and severely adverse. The main question is whether the bank has enough capital relative to the required minimum threshold that would absorb losses if one of the two adverse scenarios materialises. If the capital buffer of a credit institution turns out to be insufficient, this bank is required either to recapitalize or to deleverage. Thus the stress test reveals which banks are capital-constrained and which are not. It follows then that lending by capital-constrained institutions should not respond to monetary loosening in the US since they do not have spare riskbearing capacity. Using loan-level data, the authors test this hypothesis by looking at the cross-border lending of the US banks to borrowers in emerging markets. They find that, indeed, the cross-border lending of capital-constrained banks, i.e. those with a smaller capital surplus, responded less to monetary easing in the US than the lending of banks with a greater capital surplus. They conclude that the stress tests in the US, which can be viewed as a prudential intervention, partially offset the expansionary effect of the US monetary policy on cross-border flow of credit. Without the US stress tests, capital inflows to emerging markets would have been even more massive.

Imbierowicz et al. (forthcoming) take the domestic perspective. They study how changes in capital requirements in Germany affected the transmission of euro area monetary policy to domestic lending and loan interest rates. Two major 
prudential actions were undertaken by German prudential authorities over the 2008-2018 time period considered. First, in the course of the transition to Basel II, in 2008, banks were allowed to switch from the standardised approach to the determination of the risk weights of loans and other risky assets, which are inputs to the capital ratio, to an alternative approach based on internal ratings. The latter method gave banks more flexibility, and the outcome was that the average risk weight for each type of loan declined. Second, as part of preparation for the adoption of Basel III, in 2014, the regulators started to gradually increase capital requirements, introducing capital surcharges for Systemically Important Financial Institutions (SIFIs). The study finds a negative effect of capital requirements on lending for banks with low excess capital but no significant effect for banks with high excess capital. Monetary policy in the euro area has a positive effect on loan rates, with a tightening having a disproportionately stronger effect quantitatively than a loosening. The negative effect of monetary loosening on the lending of banks with high excess capital is statistically and economically significant, but the effect is insignificant for low-excess-capital banks. Monetary tightening is not found to affect lending. Finally, capital requirements affect the transmission of monetary policy into loan rates, but not into the growth of lending. Higher capital requirements mute the response of loan rates to shifts in monetary policy. The effect is more pronounced for banks with high excess capital and for episodes of monetary tightening.

Bussière et al. (forthcoming) take the perspective of two systemic banking centres: France, a core member of the euro area, and the UK. They look at the outward transmission of home monetary policy. The banking sector of France features a few institutions with Global Systemically Important Bank (GSIB) status, such as Société Générale and BNP Paribas. The UK is home to many banks, both national and foreign owned. The study addresses two main research questions. First, is the transmission of home monetary policy to the crossborder lending of home banks affected by the domestic prudential policy stance in the destination country? In terms of specifications (1) and (2), $M$ is monetary policy shock at home, $Y$ is the cross-border claims of home banks, which now has two cross-sectional dimensions, one for the bank and the other for the destination country, and $P$ is the prudential policy stance in the destination country. Second, does the size of a bank or the GSIB status of its parent matter in terms of the offsetting effect of the prudential policy stance in the destination country? The study finds a statistically and economically significant effect of the insulating role of domestic prudential policies in recipient countries on the cross-border lending of French and British banks. Surprisingly, the estimated effect does not depend on the size of the bank for France, but it does depend on size, and is stronger for larger banks, for the UK. The authors hypothesise that the difference in this finding between the two countries might be driven by the fact the headquarters office and a subsidiary office of the same institution are 
likely to be involved in different kinds of lending, with the headquarters focusing more on lending based on long-term relationships, e.g. foreign subsidiaries of home-based corporates, whereas subsidiary offices specialise in wholesale lending. The second type of lending is more pro-cyclical in the sense that it is more responsive to monetary policy at home and domestic prudential policy in recipient countries. The authors confirm this conjecture empirically. They find that the cross-border lending of banks headquartered in France is less procyclical than the cross-border lending of their affiliates in the UK. They label this pattern the 'London Bridge' effect: French global banks use the UK not only as the destination of their cross-border lending activities, but also as an investment base. Similarly, and consistent with the conjecture, the cross-border lending of banks headquartered in the UK is found to be less pro-cyclical than the crossborder lending of UK-located affiliates of foreign banks.

The paper by Bush et al. (forthcoming) analyses the experiences of three emerging market economies - Chile, Mexico, and Russia. There is much common among these three economies: all of them are major primary commodity exporters, they have floating exchange rates, and they practice inflation targeting. Like most emerging market economies, they have been influenced by the Global Financial Cycle. As for prudential polices, Russia, perhaps, has experimented with them more actively than the two others. The most remarkable prudential interventions were changes of reserve requirements for foreign-currency liabilities in the $2000 \mathrm{~s}$, in order to curb massive capital inflows, and in the $2010 \mathrm{~s}$, in order to promote the dedollarisation of private sector liabilities, and also the raising of risk weights for unsecured consumer credit to high-risk borrowers in the 2010s. Chile changed LTV caps for mortgages and reserve requirements for foreign-currency deposits. Mexico applied consumer and mortgage related policies that involved changes in the requirements for loans loss provisions. Baseline regressions with the aggregate prudential policy index produce mixed results. There is evidence that a moderately tight stance - i.e. +1 according to Cerutti et al.'s (2017) codification - of prudential policy in Russia offsets a third of the effect of foreign monetary policy on domestic lending. No such evidence is found for Mexico. In the case of Chile, the foreign monetary-domestic prudential interaction is statistically and economically significant, suggesting an insulating effect of domestic prudential policy, although the primary effect of inward transmission on credit growth is not statistically significant and is quantitatively small. The authors also investigate the effectiveness of sectorspecific prudential instruments. For reserve requirements for foreign currency deposits, regressions for Russia reconfirm the insulating effect of domestic prudential policies in the case of loans denominated in foreign currency. For Chile, domestic prudential policy reinforces the effect of foreign monetary policy for foreign-currency denominated loans but offsets it for domestic- 
currency denominated loans. The authors speculate that the opposite signs of the two estimates might reflect a substitution toward less expensive funding on the side of bank customers in response to a change in foreign conditions relative to domestic monetary conditions. For two other prudential instruments targeting, respectively, mortgage loans and consumer credit, the empirical evidence is even less conclusive.

Cao et al. (forthcoming) consider the case of Norway and Sweden. Both are small, open, advanced economies with well-developed banking sectors. The baseline regressions give somewhat mixed results. For Norway, it is found that a monetary tightening abroad produces a spike in domestic lending, which is counterintuitive. The interaction of domestic macroprudential policy and foreign monetary policy has a negative sign, which suggests that domestic prudential policy dampens the expansionary effect of foreign monetary tightening. In an attempt to solve this puzzle, the authors consider an alternative proxy for the cost of funding for Norwegian banks, namely, the interest differential between the Norwegian money market rate and the LIBOR, adjusted for changes in the exchange rate of the Norwegian Krone. The authors speculate that this variable is more relevant as an indicator of the cost of funding because of two features of the Norwegian economy: (i) the country is a major oil exporter, and (ii) its currency is perceived by international investors as a safe haven. Regressions for Norway with exchange-rate-adjusted interest differential produce results that are more in line with the conventional wisdom: changes in foreign monetary policy that effectively raise the cost of funding for Norwegian banks depress domestic lending, whereas a tighter domestic prudential policy stance alleviates this effect. For Sweden, the regressions yield the anticipated results: a monetary tightening in systemic economies has a negative effect on domestic lending, whereas a tighter domestic prudential policy stance plays an insulating role. Remarkably, the most relevant channel variable appears to be the currency exposure of liabilities. The specification where the proxy for global financial conditions is the average of monetary policy shocks in three centre economies, the US, the UK, and the euro area, weighted by the fraction of a bank's liabilities in the respective currencies produces the strongest results.

Everett et al. (forthcoming) takes the perspective of two small, open economies of the euro area, Ireland and the Netherlands. They investigate how domestic prudential policy affects the transmission of domestic monetary policy via mortgage lending, i.e. monetary policy in the euro area, and inward monetary transmission from the US and the UK. The paper finds mixed results. Domestic prudential policy affects mortgage lending by Irish banks, whereas, in the Netherlands, the main driver of mortgage lending is monetary policy in the euro area. Furthermore, tighter prudential policy moderates the effect of euro-area monetary policy on mortgage lending in Ireland, but not in the 
Netherlands. Finally, foreign monetary policy does not affect mortgage lending in Ireland but has a statistically and economically significant effect on mortgage lending in the Netherlands, and there is weak evidence that lender-targeting prudential policies alleviate this effect.

Avdjiev et al. (forthcoming) is a study implemented by economists of the BIS. The paper uses Locational Banking Statistics at the country level that contain data on cross-border bank flows for all pairs of reporting countries. The research question they investigate is the interaction of prudential policies in a host country and in a home country with the US monetary policy. To the extent that the majority of cross-border credit is denominated in the US dollars, the monetary policy of the US Federal Reserve is the principal determinant of the cost of dollar funding, and, therefore, the authors focus exclusively on the US monetary policy. They run two sets of panel regressions. The first is rather conventional and akin to other IBRN studies, though done on country-pair-level data. The dependent variable is the change in the cross-border claims of banks in a home country to counterparties in a host country. The explanatory variables of interest are the US monetary policy SVAR shock (estimated as in Gertler and Karadi, 2015) and its pairwise interactions with the lagged stance of prudential policy in the home and in the host countries. The second complementary set of panel regressions is rather innovative. The authors employ the approach recently developed by Amiti and Weinstein (2018) in a bank-borrower context. This method allows, in a flexible way, the decomposition of every bilateral crossborder flow into three components: (i) global, (ii) home-country-specific, and (iii) host-country-specific. The global component is presumably related mainly to the US monetary policy and other global factors such as VIX, whereas the host and home factors should reflect domestic conditions in the respective countries, including the stance of prudential policy. Performing such decomposition, the authors run panel regressions for each of the two country-specific components separately where the regressors of interest are the US monetary policy, prudential policy in the respective country, and their interaction. The findings suggest that some prudential policy measures, both in the home and in the host country, have an expansionary effect on cross-border lending, whereas some others have a contractionary effect.

Coman and Lloyd (2019) use country-level data and look specifically at emerging market economies. They study to what extent the stance of domestic prudential policies in emerging markets can reshape international monetary transmission from the US. They estimate a set of fixed effects panel regressions for 29 emerging economies. The paper applies the so-called local projections method (LPM) developed in Jordà (2005). This can be viewed as a more flexible alternative to a more conventional SVAR approach in constructing impulse response functions, which describe the dynamic response of the variable of interest. The idea is rather straightforward: If one has a proxy for the structural 
shock of interest, say $M$, which is properly identified, then the response of the variable of interest $Y$ in $h$ periods after the shock hits can be obtained from the OLS regression of $Y$ on the $h$-th lag of the shock $M$ and the controls. If the identification of the shock of interest is reliable (which is a big if indeed), then this shock is exogenous to all other determinants of $Y$ and hence the OLS will yield a consistent estimate of the impulse response. In general, Coman and Lloyd's (2019) specification is similar to equation (1), except that they use country-level rather than bank-level data, and for each value of the horizon $h$, they run a separate panel regression. Collecting the estimated impulse responses from regressions for different horizons $h$ allows them to construct dynamic impulse responses. The US monetary policy shocks are identified according to the Gertler and Karadi (2015) approach using monetary surprises as external instruments. The variable of interest is the interaction of the domestic prudential stance one month before the shock hits and the US monetary shock itself. The US monetary policy is found to have an economically and statistically significant effect on credit, house prices, and inflation in emerging economies, and the effect is much more pronounced for these countries compared with advanced economies. A monetary tightening in the US by 1 p.p. leads to a contraction of total credit by $7 \%$ and bank credit by $5 \%$ at the 5 -quarter horizon. House prices decline by $2 \%$ in three quarters, CPI inflation by $2 \%$ in six quarters. A moderate, by +1 according to the Cerutti et al.'s (2017) codification, tightening of domestic prudential policy just in advance of the US monetary policy tightening has a mitigating effect on inward monetary transmission, which equals about $1 \%$ for total and bank credit over a 4-6 quarter horizon. Among individual policy instruments, the two aiming to 'dampen' the cycle, namely, reserve requirements and LTV limits, are found to be most powerful. One interesting finding is that the interaction between domestic prudential policy and the US monetary policy does not depend on the exchange rate regime adopted in the recipient country.

There are three broad lessons that can be drawn from the IBRN initiative on the interaction of monetary and macroprudential policies. First, domestic prudential policy in recipient economies can partially offset inward transmission from systemic economies to domestic lending. The strength of this offsetting effect is heterogeneous across banks in source countries and depends on the business model of financial institution. Second, the stance of prudential policy in the source economy also matters and can affect the intensity of outward monetary transmission. Finally, there is much heterogeneity in the strength of effect across different prudential instruments. 


\section{References}

Amiti, M. and Weinstein, D. (2018). How Much Do Idiosyncratic Bank Shock Affect Investment? Evidence from Matched Bank-Firm Loan Data. Journal of Political Economy, 126(2), pp. 525-587.

Avdjiev, S., Hardy, B., McGuire, P. and von Peter, G. (forthcoming). Home Sweet Host: Prudential and Monetary Policy Spillovers through Global Banks.

Review of International Economics, special issue.

Blanchard, O.-J. (2017). Currency Wars, Coordination, and Capital Controls. International Journal of Central Banking, 13(2), pp. 283-308.

Bruno, V. and Shin, H. S. (2015). Cross-Border Banking and Global Liquidity. Review of Economic Studies, 82(2), pp. 535-564.

Bush, G., Gomez, T., Jara, A., Lopez-Castanon, C., Moreno, D., Styrin, K. and Ushakova, Y. (forthcoming). Macroprudential Policy and the Inward Transmission of Monetary Policy Shocks: The case of Chile, Mexico, and Russia. Review of International Economics, special issue.

Bussière, M., Gills, R., Lloyd, S., Meunier, B., Pedrono, J., Reinhardt, D. and Sowerbutts, R. (forthcoming). Le Pont de Londres: Interactions between Monetary and Prudential Policies in Cross-Border Lending. Review of International Economics, special issue.

Cao, J., Dinger, V., Grodecka-Messi, A., Juelsrud, R. and Zhang, X. (forthcoming). The Interaction between Macroprudential and Monetary Policies: The Cases of Norway and Sweden. Review of International Economics, special issue.

Cerutti, E., Correa, R., Fiorentino, E. and Segalla, E. (2017). Changes in Prudential Policy Instruments - A New Cross-Country Database. International Journal of Central Banking, 13(2), pp. 477-503.

Coman, A. and Lloyd, S.P. (2019). In the Face of Spillovers: Prudential Policies in Emerging Economies. Bank of England Working Paper, N 828.

Everett, M., de Haan, J., Jansen, D., McQuade, P. and Samarina, A. (forthcoming). Mortgage Lending, Monetary Policy, and Prudential Measures in Small Euro-Area Economies: Evidence from Ireland and the Netherlands. Review of International Economics, special issue.

Gertler, M. and Karadi, P. (2015). Monetary Policy Surprises, Credit Costs, and Economic Activity. American Economic Journal: Macroeconomics, 7(1), pp. 44-76. doi: $10.1257 /$ mac.20130329

Gilchrist, S. and Zakrajšek, E. (2012). Credit Spreads and Business Cycle Fluctuations. American Economic Review, 102(4), pp. 1692-1720. doi: 10.1257/aer.102.4.1692

Gürkaynak, R. S., Sack, B. and Swanson, E. T. (2005), Do Actions Speak Louder than Words? The Response of Asset Prices to Monetary Policy Actions and Statements. International Journal of Central Banking, 1(1), pp. 55-93.

Hamilton, J. D. and Wu, J. C. (2012). Identification and Estimation of Gaussian Term Structure Models. Journal of Econometrics, 168(2), pp. 315-331.

doi: 10.1016/j.jeconom.2012.01.035 
Imbierowicz, B., Löffler, A. and Vogel, U. (forthcoming). The Transmission of Bank Capital Requirements and Monetary Policy to Bank Lending. Review of International Economics, special issue.

Jordà, O. (2005). Estimation and Inference of Impulse Responses by Local Projections. American Economic Review, 95(1), pp. 161-182. doi: 10.1257/0002828053828518

Kashyap, A. K. and Stein, J. C. (2000). What Do a Million Observations of Banks Say about the Transmission of Monetary Policy? American Economic Review, 90(3), pp. 407-428. doi: 10.1257/aer.90.3.407

Krippner, L. (2015). Zero Lower Bound Term Structure Modeling: A Practitioner's Guide. Palgrave-Macmillan.

Mertens, K. and Ravn, M. O. (2013). The Dynamic Effects of Personal and Corporate Income Tax Changes in the United States. American Economic Review, 103(4), pp. 1212-1247. doi: 10.1257/aer.103.4.1212

Miranda-Agrippino, S. and Rey, H. (2020). U.S. Monetary Policy and the Global Financial Sycle. Review of Economic Studies, rdaa019. doi: 10.1093/restud/rdaa019

Niepmann, F., Schmidt-Eisenlohr, T. and Liu, E. (forthcoming). The Effect of U.S. Stress Tests on Monetary Policy Spillovers to Emerging Markets. Review of International Economics, special issue.

Passari, E. and Rey, H. (2015). Financial Flows and the International Monetary System. Economic Journal, 125(584), pp. 675-698. doi: 10.1111/ecoj.12268

Piazzesi, M. (2010). Affine Term Structure Models. In: Y. Ait-sahalia and L. P. Hansen, eds. Handbook of Financial Econometrics: Tools and Techniques. Elsevier, pp. 691-766.

Rajan, R. (2015). Competitive Monetary Easing: Is It Yesterday Once More? Macroeconomics and Finance in Emerging Market Economies, 8(1-2), pp. 5-16.

Repullo, R. and Suarez, J. (2013). The Procyclical Effects of Bank Capital Regulation. Review of Financial Studies, 26(2), pp. 452-490. doi: 10.1093/rfs/hhs118

Rey, H. (2015, revised 2018). Dilemma Not Trilemma: The Global Financial Cycle and Monetary Policy Independence. NBER Working Paper, N 21162.

Stein, J. C. (2013). Overheating in Credit Markets: Origins, Measurement, and Policy Responses. [Speech] 'Restoring Household Financial Stability after the Great Recession: Why Household Balance Sheets Matter,' a Research Symposium sponsored by the Federal Reserve Bank of St. Louis, St. Louis, Missouri, 7 February.

Stock, J. H. and Watson, M. W. (2018). Identification and Estimation of Dynamic Causal Effects in Macroeconomics Using External Instruments. Economic Journal, 128(610), pp. 917-948. doi: 10.1111/ecoj.12593

Wu, J. and Xia, F. (2016). Measuring the Macroeconomic Impact of Monetary Policy at the Zero Lower Bound. Journal of Money, Credit, and Banking, 48(2-3), pp. 253-291. doi: $10.1111 /$ jmcb. 12300 